\title{
LCP 薄肉射出成形品の熱間反り解析
}

\author{
杉田 寿 $*^{* 1} \cdot$ 瀬 戸 雅 宏*2 $・ 山$ 部 昌*2

\section{Analysis of the Hot Warpage Deformation of a Thin-wall LCP Injection Molded Part}

\author{
Sugita, Toshio*1/Seto, Masahiro*2/Yamabe, Masashi*2
}

\begin{abstract}
Hot warpage of LCP (Liquid Crystalline Polymer) injection molded part used in hot environments is strongly influenced by anisotropy generated by shearing strain in injection molding process. Therefore, it is important to quantitatively clarify the anisotropic distribution affected by the molding process. In this paper, we examined an application of molecular orientation measurement using the X-ray diffraction of the small spot to clarify distribution of anisotropic coefficient of thermal expansion (CTE) of small, thin LCP injection molded parts that are difficult to measure by the TMA. And we converted molecular orientation ratio to local anisotropic CTE. Furthermore, we analyzed hot warpage by structure analysis in consideration of anisotropic CTE distribution. We compared the results of the analysis with the measurement of the hot warpage and discussed influence to give analysis precision. As a result, the following points were obtained ;

(1) It was possible to clarify the distribution of anisotropic CTE of the LCP part from correlation between molecular orientation ratio measured by X-ray diffraction and anisotropic CTE.

(2) It was possible to predict the direction of the hot warpage qualitatively by structure analysis in consideration of anisotropic CTE distribution.

(3) Because a difference between molecular orientation of LCP and the orientation of grass fiber (GF) occurs in the flow of the narrow corner, it is necessary to consider the interference of GF for calculation of anisotropic CTE.

Key words : Liquid Crystalline Polymer, Orientation, Anisotropy, Injection Molding
\end{abstract}

\section{1. 緒言}

液晶ポリマー（以下，LCP）は高流動・高弾性率・低線 膨張係数といった優れた特性から, 小型・薄肉・微細形状 の射出成形品に広く用いられる ${ }^{1,2)}$. また，耐熱性が高い ため, 成形品が $200^{\circ} \mathrm{C}$ 以上の高温環境にさらされる用途に

${ }^{* 1}$ 金沢工業大学大学院

Kanazawa Institute of Technology 白山市八束穂 3-1（敄924-0838）

3-1 Yatsukaho, Hakusan, Ishikawa, Japan

パナソニック侏エコソリューションズ社

Panasonic Corporation Eco Solutions company

門真市大字門真 1048（テ571-8686）

1048 Kadoma, Kadoma, Osaka, Japan

sugita.toshio@jp.panasonic.com

*2 金沢工業大学

Kanazawa Institute of Technology

白山市八束穂 3-1（开924-0838）

3-1 Yatsukaho, Hakusan, Ishikawa, Japan

2016. 12.5 受理
も使用される。このような使用環境の変化に伴って成形品 各部の寸法は線膨張係数に応じて膨張・収縮する. 成形品 各部で膨張・収縮に分布や異方性がある場合, 成形品に反 り変形（熱間反り）が発生し，部品として使用する上での 様々な問題が発生する.

射出成形品の熱間反り変形挙動を解析するためには，成 形品各部の線膨張係数分布を知る必要がある. 特に LCP では，剛直な分子構造により強い異方性が発生するため, 線膨張係数は分子配向状態に強く影響される ${ }^{3}$. しかしな がら, 近年の電子機器等の小型化 肉化設計が求められる射出成形品各部において, 局所の線 膨張係数異方性を直接測定することは困難である。そこで, 解析したい小型成形品の分子配向分布を実測し, 別に分子 配向と共に測定した線膨張係数との関係を調べることによ り，分布を把握できると考えられる.

本研究では，従来のマイクロ波分子配向測定の測定範囲 より小さく測定が不可能な小型・薄肉の LCP 射出成形品 の線膨張倸数分布を把握するために，まず，マイクロ波分 
子配向測定および線膨張係数を実測評価できる平板成形品 において，局所分子配向と線膨張係数の関係を評価する. 局所分子配向測定には直径 $100 \mu \mathrm{m}$ の小スポットの X 線 回折を用い，マイクロ波分子配向測定との相関を確認する ことで局所の分子配向測定への適用性を評価する。また， $\mathrm{X}$ 線回折による分子配向と線膨張係数異方性の相関データ から実験式を得る.さらに, 小型・薄肉な LCP 射出成形 品において, 局所の分子配向を X 線回折により測定し, 上記の実験式により線膨張係数異方性に変換する.そして, 線膨張係数異方性の分布を与えた構造解析により熱間反り 変形を解析し, 実際の成形品の熱間反りと比較する.

\section{2. 実験方法}

\section{1 平板成形品の作製}

分子配向および線膨張係数異方性の実測から相関関係を 評価するための平板成形品は図 1 に示すとおり, 幅 $50 \times$ 長さ $100 \times$ 厚さ $0.5 \mathrm{~mm}$ の平板部と流動方向を揃えるファ ンゲートからなる. 供試材料は平均繊維長 $88 \mu \mathrm{m}$ のガラ ス繊維（以下，GF）を添加したI 型 LCP を用いた. 分子 配向および線膨張係数を評価する試料は図中の破線で示す $35 \times 35 \mathrm{~mm}$ の範囲を切り出した後, 研削により厚み方向 に $0.1 \mathrm{~mm}$ ずつ 5 分割し, 表面から 3 層を順にSkin 層 (裏 面 $0.4 \mathrm{~mm}$ 研削), Middle 層 (表面 $0.1 \mathrm{~mm}$, 裏面 $0.3 \mathrm{~mm}$ 研削), Core 層（表面 $0.2 \mathrm{~mm}$, 裏面 $0.2 \mathrm{~mm}$ 研削）とし た. 配向状態が摩擦熱により変化しないよう, 冷却水を十 分に与えて加工した. なお, 残り 2 層は厚み方向に対称な 流れと仮定して省略した. 後述のマイクロ波分子配向計の 測定には $35 \times 35 \mathrm{~mm}$ のサンプルのまま用い, X 線回折に よる分子配向評価は図中の（XRD）で示す直径 $100 \mu \mathrm{m}$ の 点において行った. TMAによる線膨張係数 (CTE) 異方 性の評価は図中の流動方向 (Machine Direction, 以下 MD) および直交方向（Transverse Direction，以下 TD）それ ぞれにおいて幅 $5 \mathrm{~mm}$ のサンプルを切り出した.

成形はプランジャ径 $40 \mathrm{~mm}$, 最大型締力 $1764 \mathrm{kN}$ のイ ンライン式射出成形機（Si-180 III ，東洋機械金属(侏製）を 用いて表 1 の条件にて行った.

\section{2 分子配向測定}

\subsection{1 マイクロ波分子配向計}

マイクロ波分子配向計 (MOA-3012A, 王子計測機器(株) は, 分子の配向によって配向方向と直角方向でマイクロ波 の透過強度が異なることを利用した装置である．測定方法
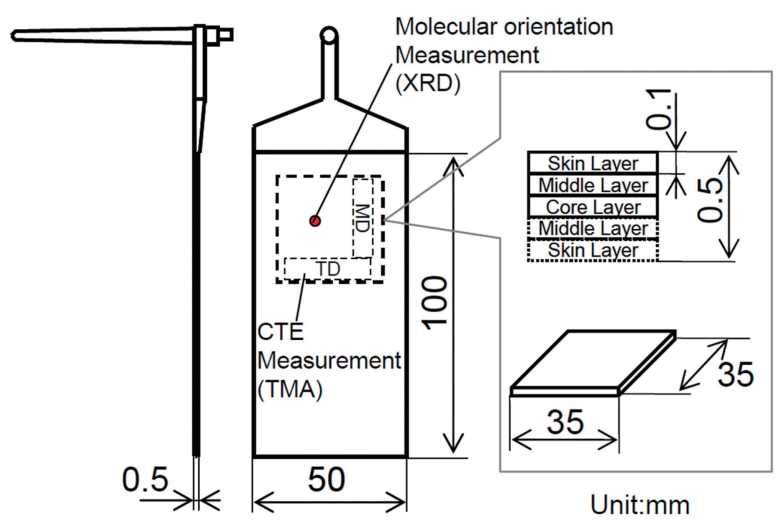

Fig. 1 Geometry of injection molded plate
Table 1 Injection molding conditions

\begin{tabular}{l|r}
\hline \hline Injection rate $\left[\mathrm{cm}^{3} / \mathrm{s}\right]$ & $31.4,62.8,125.7$ \\
Injection speed $[\mathrm{mm} / \mathrm{s}]$ & 100 \\
\hline Maximum filling pressure $[\mathrm{MPa}]$ & 50 \\
\hline Packing pressure $[\mathrm{MPa}]$ & 5 \\
\hline Packing time $[\mathrm{s}]$ & 100 \\
\hline Cooling time $[\mathrm{s}]$ & 380 \\
\hline Temperature of resin $\left[{ }^{\circ} \mathrm{C}\right]$ & 80 \\
\hline Temperature of mold $\left[{ }^{\circ} \mathrm{C}\right]$ &
\end{tabular}

は，試験片を回転させながら一定強度のマイクロ波を照射 し, 分子の配向によって変化する透過マイクロ波の強度を 測定した。そして，配向方向と直角方向の透過マイクロ波 強度の比を分子配向度として出力した.

\subsubsection{X 線回折}

広角 X 線回折装置（株りリ゙ク製 RINT-RAPID）を用い て測定径 $100 \mu \mathrm{m}$ の透過式広角 $\mathrm{X}$ 線回折により分子配向 を定量化したＸ線回折は物質に X 線を照射した際に散 乱した X 線の干渉により原子の配列から結晶構造を解析 する手法である. LCP 分子においては, 回折角 $2 \theta=19.8^{\circ}$ において強い干渉が起こる. 図 2 に LCP 射出成形品の X 線回折により得られた，干渉を表すデバイ・シェラー環像 を示す. 図中における配向方向（流動方向）は $0^{\circ}$ であり, 流動方向の直交方向である $90^{\circ}, 270^{\circ}$ に強い干渉が確認で きる.さらに，分子配向の強さを示す分子配向度の評価の ため, デバイ・シェラー環像の回折角 $2 \theta=19.8^{\circ}$ におけ る円周方向の強度を配向角 $360^{\circ}$ に展開した, 図 3 に示す 強度チャートを作成した. 配向角は流動直交方向を示す強 度の 2 つのピークの中間となる角度 $\beta$ により読み取り, 分子配向度 $M O R_{x d d}$ は, は図中のバックグラウンドに対す るピークの半值幅 $W i$ を読み取り, (1)式を用いて算出した ${ }^{5)}$.

$$
M O R_{x r d}=\frac{360^{\circ}-\Sigma W_{i}}{360^{\circ}} \times 100
$$

\section{3 線膨張係数評価}

分子配向評価部分から図 1 に示す位置で流動方向 (MD) と直交方向（TD）の試験片を切り出した後, 熱機械分析 装置（TMA-50，株島津製作所製）を用いて熱ひずみ量を 測定し，JIS K7197 に基づき線膨張係数を算出した。先に

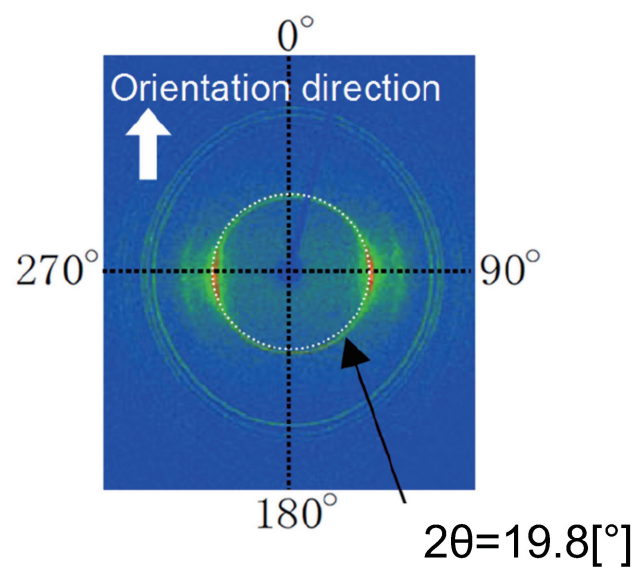

Fig. 2 Debye-Scherrer ring of X-ray diffraction 


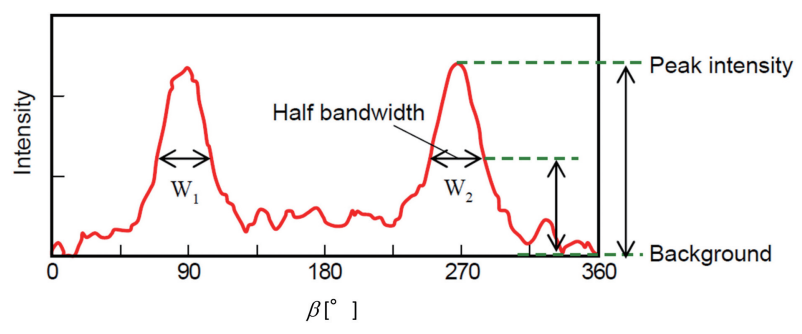

Fig. 3 Intensity chart of $2 \theta=19.8^{\circ}$

得られた分子配向度と線膨張係数異方性との関係について, 相関関係を評価し, 分子配向度から線膨張係数異方性を算 出するための実験式を得る.

\section{4 小型箱形成形品の作製}

図 4 に熱間反りを評価する小型箱型成形品の形状および 試料作製のパラメータを示す. 成形品の形状は長さ 17.8 $\times$ 幅 $1.83 \times$ 高さ $0.4 \mathrm{~mm}$ の直方体に, 長さ $16.5 \mathrm{~mm}$, 幅 および深さ可変の開口部をもつ箱形状である. A-A 断面 における底面厚さ $t_{b}$, 側面厚さ $t_{s}$ とし, 後に述べる局所の 分子配向および線膨張係数異方性の分布を評価する領域と して，側面部の下半分を piece 1, 上半分を piece 2 , 対称 面および側面部の間の底面部について, 側面側の半分を piece 3 , 対称面側の半分を piece 4 とした. 試料は $t_{b}$ およ び $t_{s}$, 金型取り数をパラメータとし, 図中に示す 4 条件で 試料を作製した。供試材料は平板と同様の平均繊維長 88 $\mu \mathrm{m}$ の GF を添加した I 型 LCP 用いた。成形はプラン ジャ径 $16 \mathrm{~mm}$, 最大型締力 $196 \mathrm{kN}$ のプリプラ式射出成形

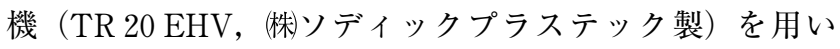
て行った.

\section{5 分子配向評価および線膨張係数への変換}

平板成形品と同様の方法で X 線回折を行い, 配向角お よび分子配向度（以下, MOR）を評価した. 評価は前述
の piece 1 piece 4 について行った. X 線回折により得ら れた MOR を用いて, 平板成形品の評価により得られる分 子配向度と線膨張係数の関係の実験式に基づき, 配向主軸 における MD および TDの線膨張係数を求めた.

\section{6 熱間反りの実測と解析}

小型箱型成形品の熱間反りの実測には，株コアーズ製の 平坦度測定装置 core $9031 \mathrm{a}$ を用いた. $25^{\circ} \mathrm{C}$ から $275^{\circ} \mathrm{C}$ の 間で昇温および降温を行う所定のプロファイルにて炉内を 温度制御し，25，230，275，230，160，25 ${ }^{\circ} \mathrm{C}$ における基 準面からの距離をレーザ変位センサにより測定した．昇温 後の $160^{\circ} \mathrm{C}$ から $25^{\circ} \mathrm{C}$ の冷却は加熱を切った状態での徐冷 とした．基準面と最大変位点の距離を平坦度とし，山反り を正，谷反りを負とした。熱間反りの解析にはANSYS (ANSYS, Inc.) を用い, 図 5 に示す有限要素解析モデル に，得られた線膨張係数の異方性と材料主軸を与え，熱間 反り実測時の熱負荷 $\left(25^{\circ} \mathrm{C}\right.$ から $275^{\circ} \mathrm{C}$ に昇温）を与えた 際の変形状態を計算し, 熱間反り変化量を求めた。解析モ デルは図中の X 方向, $\mathrm{Y}$ 方向に対称とし，4 分の 1 モデル とした.メッシュ分割は 6 面体要素で 2272 要素であり, $\mathrm{Y}-\mathrm{Z}$ 断面を $\mathrm{X}$ 方向の変位を拘束, $\mathrm{Z}-\mathrm{X}$ 断面を $\mathrm{Y}$ 方向の 変位を拘束, $\mathrm{Y}-\mathrm{Z}$ 断面と $\mathrm{Z}-\mathrm{X}$ 断面および箱形状の底面 が交差する接点を $Z$ 方向の変位を拘束した。拘束は収束 に必要な移動の抑制のみであり, モデルの変形により外部 からの力を受けない条件とした.

\section{3. 結 果}

\section{1 マイクロ波分子配向計による分子配向測定}

図 6 にマイクロ波分子配向計による層ごとの分子配向度 の測定結果を示す．射出速度 $50 \mathrm{~mm} / \mathrm{s}$ および $100 \mathrm{~mm} / \mathrm{s}$ では, Skin 層, Middle 層, Core 層の順に分子配向度は小 さくなり，金型表面に近いほど，大きなせん断ひずみが発

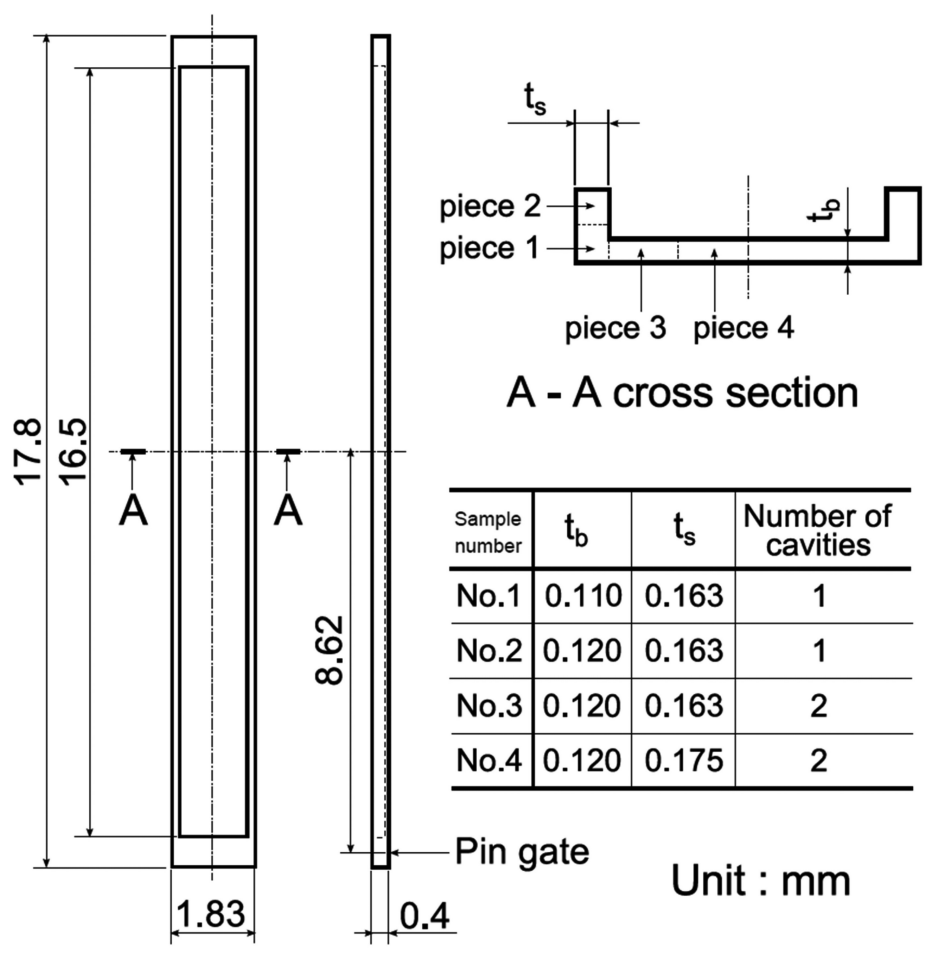

Fig. 4 Geometry of injection molded parts 


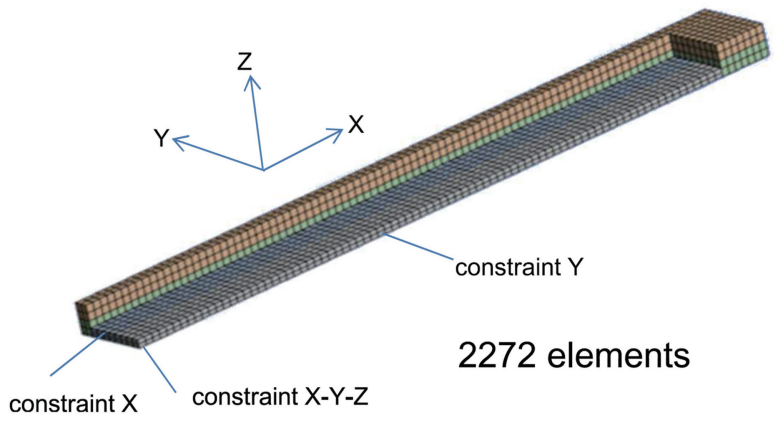

Fig. 5 FEM model for structural analysis

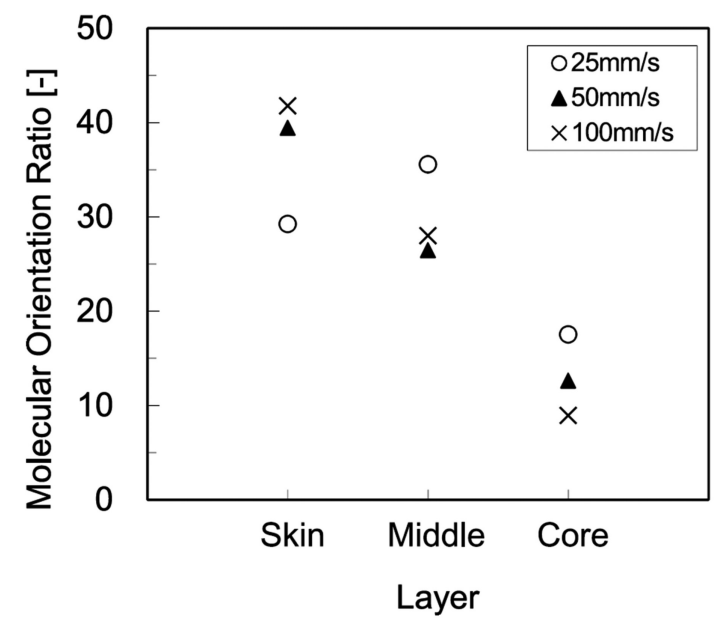

Fig. 6 Molecular orientation by layers

生していると推察される.しかし, 射出速度 $25 \mathrm{~mm} / \mathrm{s}$ の 条件では，Skin 層に比べ Middle 層の分子配向度が高い. この傾向は, 固化層が Middle 層付近まで成長した結果, 固液界面（固化層表面）における局所流速が高まることと， 分子配向は固化直前の分子が受けるせん断ひずみに依存す ることにより，Middle 層の分子配向度が Skin 層よりも高 くなるという著者ら ${ }^{6)}$ の検討結果と一致する.

\section{$3.2 X$ 線回折による配向分析}

図 7 に 線回折による層ごとの分子配向度のグラフを 示す。射出速度 $50 \mathrm{~mm} / \mathrm{s}$ および $100 \mathrm{~mm} / \mathrm{s}$ の条件で Skin 層, Middle 層, Core 層の順に分子配向度は小さいこと, 射出速度 $25 \mathrm{~mm} / \mathrm{s}$ の条件で Skin 層に比べ Middle 層の分 子配向度が高いことなど，定性的にマイクロ波分子配向計 の結果と同じ傾向を示している.

\section{3 マイクロ波分子配向計と $X$ 線回折の分子配向度相 関評価}

マイクロ波分子配向計および X 線回折の分子配向度の 測定結果から両者の相関性を評価するために, 図 8 に横軸 にマイクロ波分子配向計，縦軸にX 線回折の分子配向測 定結果をとったグラフを示す。図中の線分は各射出速度条 件の最小二乗法による 1 次関数近似を示す. 相関係数 $\mathrm{R}$ は 0.86 となり, 強い正の相関がある.

\section{4 線膨張係数と $X$ 線回折の分子配向度相関評価}

図 9 に X 線回折により求めた分子配向度と MD および TD の線膨張係数の関係を示す. 各分子配向度において $\mathrm{TD}$ 線膨張係数が $\mathrm{MD}$ 線膨張係数より大きく, 明確な異方 性が見られた. また, 分子配向度が大きくなるにつれて TD

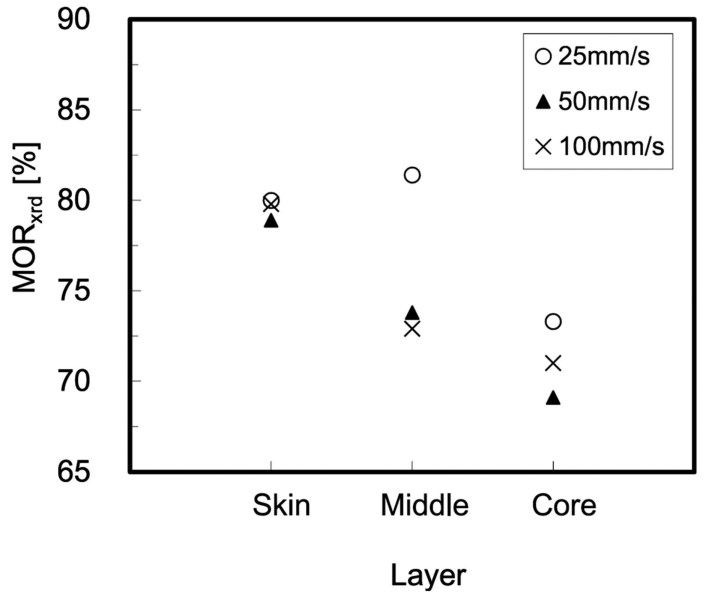

Fig. 7 Molecular orientation measured by X-ray diffraction by layers

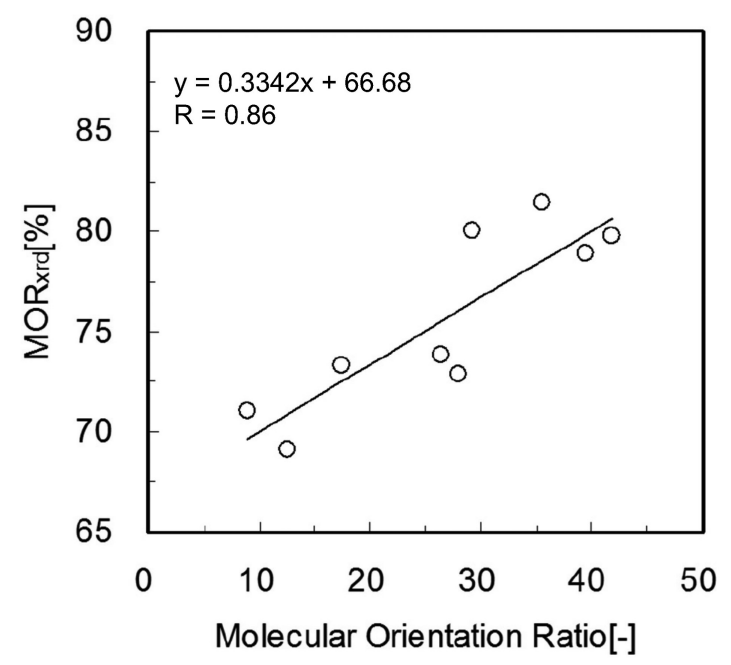

Fig. 8 Relationship about MOR between the molecular orientation analyzer and X-ray diffraction

線膨張係数は大きく, MD 線膨張係数は小さくなり, 異方 性が強くなる傾向が確認された。 TD, MD ともにその傾向 は分子配向度との相関が見られるため，この関係を材料特 性データとして蓄積しておけば，X 線回折により成形品の 線膨張係数の異方性分布を把握することが可能であると考 えられる。

\section{5 熱間反りの実測}

図 10 に実測した各条件の熱間反りの変化を示す。また, 図中に炉内の温度変化も合わせて示す. 図 4 に示した各条 件（No.1〜No.4）において，すべての条件で昇温時に谷 反りが進み，降温時に大きく山反りする不可逆な変化の傾 向を示した。これは，昇温時には成形時の残留ひずみが緩 和する効果と線膨張係数の影響で変形し，降温時には線膨 張係数の影響で変形していると推察される. そのため, 昇 温時の熱間反り挙動の解析には, 残留ひずみ生成プロセス まで考慮する必要があると考えられる，また，図中には省 略しているが， 1 回目の昇温 $\left(25^{\circ} \mathrm{C} \sim 275^{\circ} \mathrm{C}\right)$ 以降, 1 回目 の降温 $\left(275^{\circ} \mathrm{C} \sim 25^{\circ} \mathrm{C}\right), 2$ 回目の昇温・降温 $\left(25^{\circ} \mathrm{C} \sim 275^{\circ} \mathrm{C}\right.$ $\left.\sim 25^{\circ} \mathrm{C}\right)$ において, 熱間反りの変化は可逆となることを確 認している.これは, 残留ひずみの影響がなくなっている ためと推察される. 本研究では, 線膨張係数の影響のみ考 


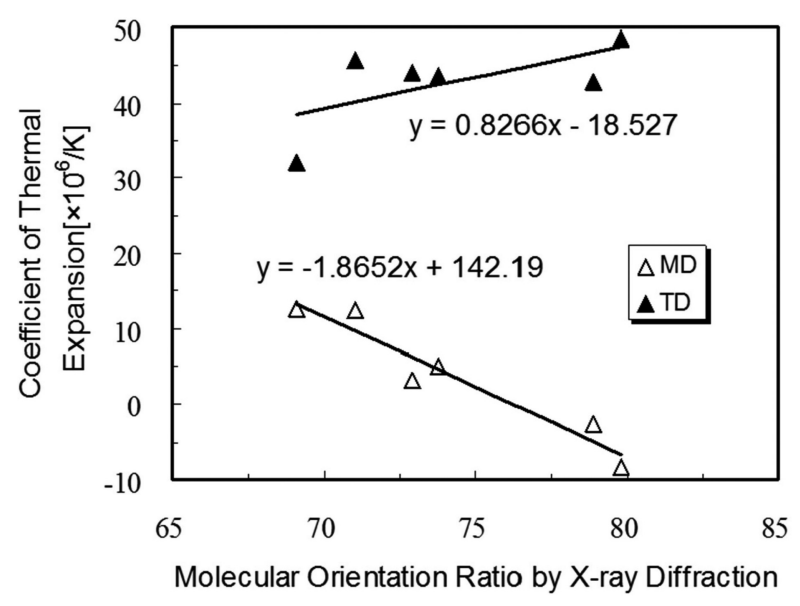

Fig. 9 Relationship between the molecular orientation by X-ray diffraction and anisotropic CTE by TMA

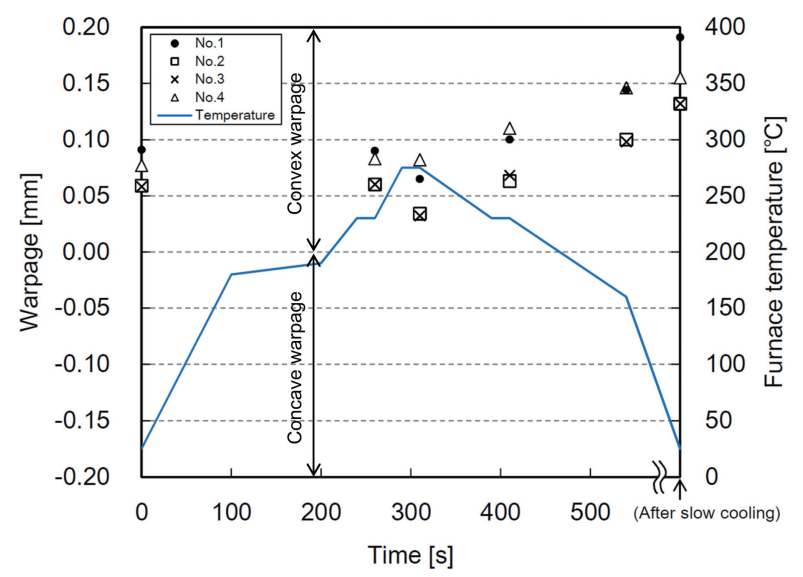

Fig. 10 Hot warpage of parts in a reflow furnace

慮するため, $25^{\circ} \mathrm{C}$ から $275^{\circ} \mathrm{C} へ$ の 2 回目以降の昇温時の 反り変化量（1 回目昇温で残留ひずみが緩和するため, 1 回目降温時の反り変化量とは絶対值が等しく反り変化の向 きが逆となる）を熱間反り変化量と定義した．また，側面 と底面の厚みの違いにより熱間反り変形挙動に違いが現れ ているが，取り数のみ異なるNo. 2 と No. 3 においては, ほぼ同じ傾向を示したため，本報告の成形品形状では，ラ ンナ等の影響よりも成形品の形状が熱間反り変形挙動を決 める要因となっていると考えられる.

\section{6 熱間反りの解析}

図 11 に熱間反り変化量の実測と解析の比較を示す。す べての条件において，実測と解析ともに負の值を示してお り，熱負荷をかけた際に谷反りが進む傾向を定性的に解析 できていると考えられる. しかし，グラフ中の斜め破線で 示す反り量の一致の線からは離れており, 成形品形状の違 いによる熱間反り変化量を定量的に解析できていないこと が分かった。

\section{4. 考察}

\section{1 成形品の線膨張係数実測と熱間反り解析}

$\mathrm{X}$ 線回折から求めた線膨張係数異方性分布では, 熱間反 りを定量的に解析できていない. そこで, 図 4 の成形品か ら TMA で測定可能なサンプルの切り出しを検討した. ダ

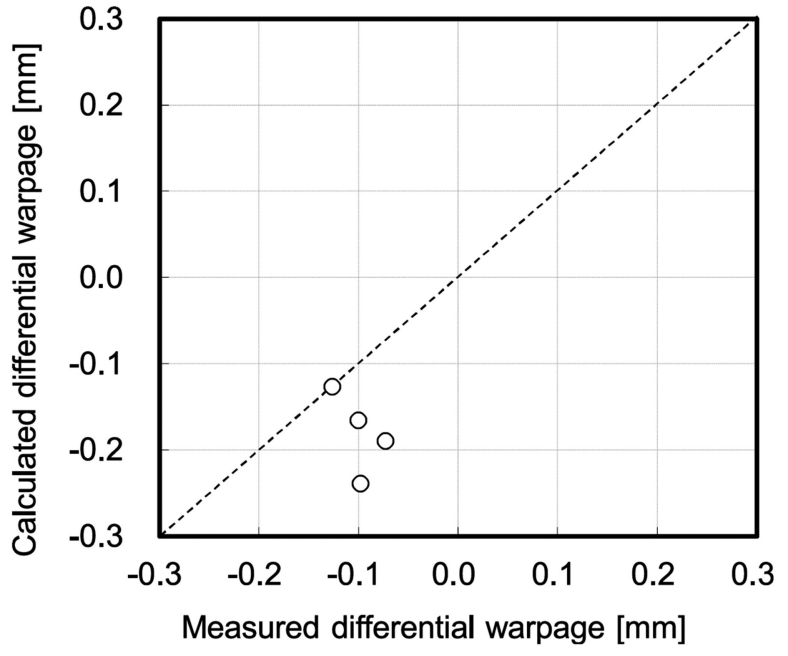

Fig. 11 Comparison of differential hot warpage between calculation and measurement

イサーを用いて piece 1〜4を分割し, MD の線膨張係数を 実測した. 細長い形状となり TD の線膨張係数は実測でき ないため, MDの線膨張係数と X 線回折で得られた配向 角から座標变換により求めた。これらの線膨張係数異方性 を与え, 解析を行った際の熱間反り変化量の実測と解析の 比較を図 12 に示す. X 線回折から求めた結果と比較し, 実測と定量的に近くなった.よって, 定量的な解析のため には，マトリクスである LCP の分子配向を評価するX 線 回折から線膨張係数の異方性を求めるだけでは実際の線膨 張係数とは異なるため, フィラー配向など他の要因の考慮 が必要であると考えられる。

\section{2 成形品の分子配向と流動}

図 13 に条件No. 1 における計量值を変えたときの小型 箱型成形品のショートショットの変化を示す. 底面に対し 側面の流動が先行している様子が見て取れる．また，底面 においては中心部が最も流動が遅い V 字形状の流動パ ターンを示している. このことから, 流速の速い側面から 底面への樹脂の流れが生じているものと推察される.図 14 に条件 No. 1 において X 線回折から得られた配向角と

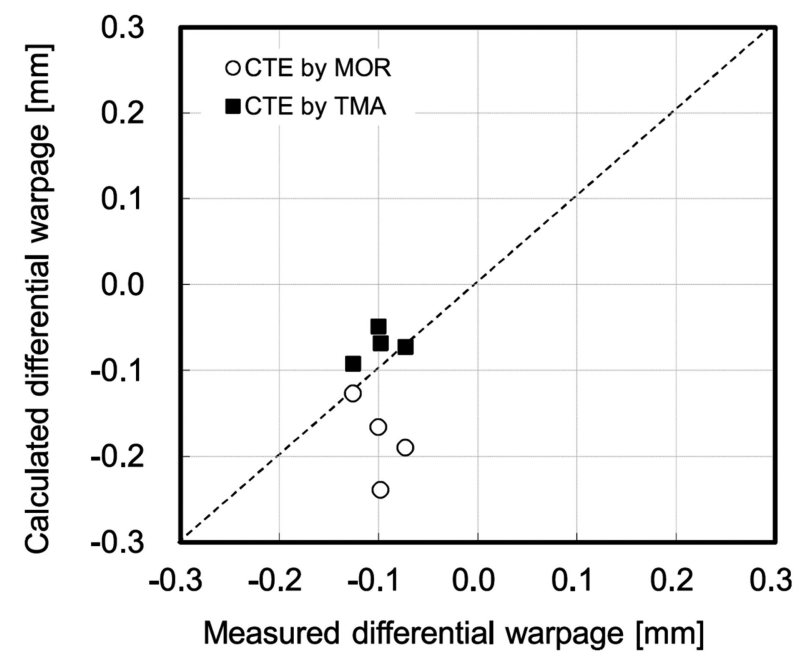

Fig. 12 Comparison of differential hot warpage between calculation and measurement 

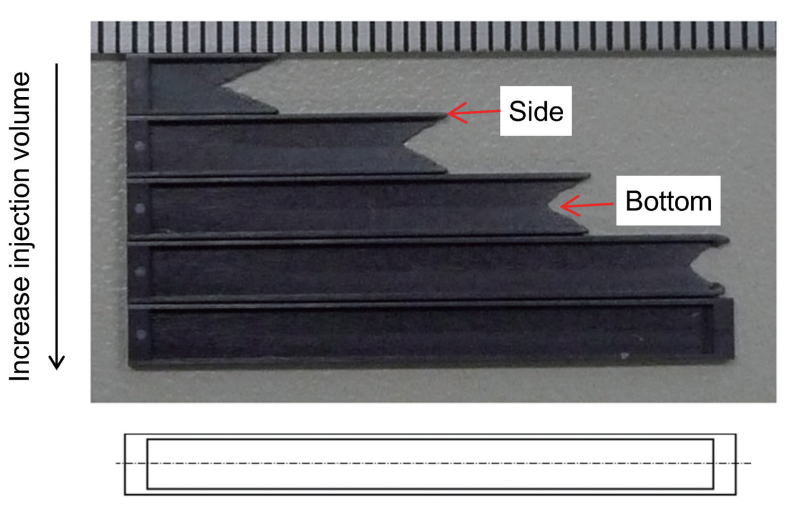

不

Fig. 13 Flow patterns of short-shot molding (shape No. 1)

MOR の piece 1〜 piece 4 における分布を示す．配向角は $\mathrm{MD}$ を $0^{\circ}$ とし, 箱形状の内側から見て時計回りの方向を 正としている。速い流動が観察された側面（piece 1 およ び piece 2) の MOR が高く，底面（piece 3 および piece 4) の MOR は低い。また, piece 3 の配向角が中心部に向かっ て $15.6^{\circ}$ と大きく傾いて扮り, 図 13 のショートショット 観察の傾向と一致している.

\section{3 フィラー配向の影響}

本研究の線膨張係数は流動方向が揃った平板成形品によ り評価している。一方，箱型成形品では側面から底面への 流動が生じており，薄肉の角部に対して GF の流動の影響 が考えられる. 鈴木ら》はマイクロフォーカス X 線 CT に より射出成形品内の GF を撮像し, 円柱フィッティングを 用いた三次元画像処理により，個々の GF の配向状態を定 量化している. そこで, 本研究の箱型成形品の piece 1 4 をX 線 CT で撮像し, 円柱フィッティング処理を行った 画像を図 15 に示す. 画像に対応する成形品の模式図を図 中に併せて示す. piece 1 と piece 3 の接続部付近に扔いて, GF が少なくなっている部分が見て取れる。これはマトリ クスである LCP の流動とフィラーである GF の流動にず れが発生していることを示している。本成形品のような $0.1 \mathrm{~mm}$ 程度の薄肉角部に損いて, フィラーがマトリクス の流動に追従していないため, 複合材料としての線膨張係 数異方性が平板の測定と X 線回折から求めたものと異 なったことが熱間反り解析の精度に影響したものと推察さ れる.このことから，小型・薄肉の LCP 射出成形品の熱 間反り解析には, 薄肉部のフィラー流動の影響を定量化す

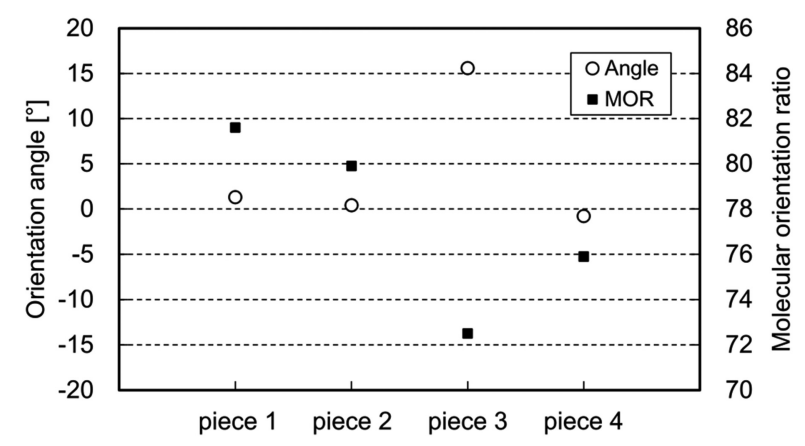

Fig. 14 Molecular orientation of part (No.1)
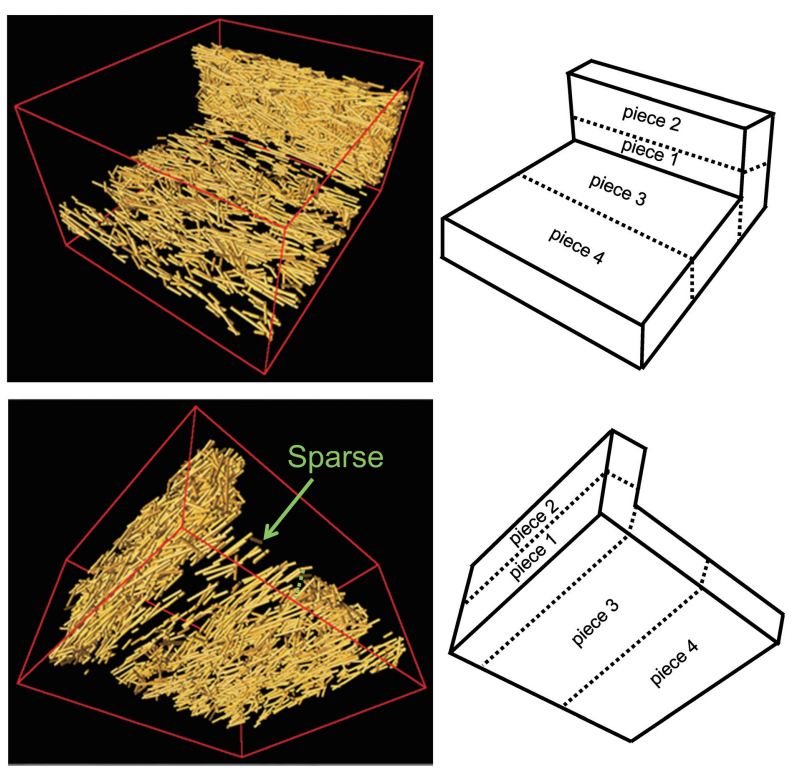

Fig. 15 Result of GF extraction by cylinder model fitting

る必要があると考えられる。

\section{5. 結言}

熱機械分析による異方性評価が困難な LCP 小型・薄肉 射出成形品を対象に, 熱間反りの要因として考えられる線 膨張係数異方性分布を定量化するため, 熱機械分析が可能 な平板成形品を用いて，小スポットでの分子配向評価への $\mathrm{X}$ 線回折の適用を従来のマイクロ波式に対して評価した。 また, 局所分子配向測定結果と線膨張係数異方性の相関関 倸を評価した。さらに，小型箱型成形品の X 線回折によ り得られた局所の分子配向度から線膨張係数異方性を求め, 構造解析により熱間反りの解析を行い, 熱間反りの実測值 と比較した。本論文で得られた結果を以下に列記する。

(1) 従来の分子配向評価方法であるマイクロ波分子配向計 と小スポット X 線回折の分子配向評価結果には相関 があり，成形品の局所の分子配向を実測できることを 確認できた。さらに，分子配向度と線膨張係数異方性 との相関関係のデータから局所の線膨張係数異方性分 布を求めることができた。

（2）小型箱型成形品の解析モデルに求めた線膨張係数異方 性分布を入力した構造解析により, 熱間反りを解析し, 熱間反りの向きを正しく予測することができた。しか し，熱間反りの定量值には差異が生じた。

（3）小型箱型成形品の薄肉角部の流動において，X 線 CT による GF 配向評価により LCP の分子配向と GF の 配向の差異を確認できた。これにより, 配向に差異が 生じない平板成形品のデータを流動形態の異なる小型 箱型成形品に適用すると異方性に差異が生じ，熱間反 り解析の精度に影響を与えると考えられる。 その対策 として，金型キャビティの薄肉角部が GF の干渉に与 える影響を考慮した線脰張係数異方性の算出が必要で あり, 今後の課題である。 
参 考 文 献

1 ）荒木克彦, 北野武：液晶ポリマーのレオロジーと成形 性，アイピーシー，7(2003)

2 ）末永純一：成形・設計のための液晶ポリマー, シグマ 出版，21(1995)

3 ）杉田寿夫, 松原永治, 瀬戸雅宏, 山部昌：成形加工'07 予稿集，187(2007)

4 ）馬場和宏：エレクトロニクス実装学会誌，10（7），509
(2007)

5 ) 理学電機(株)X 線研究所：X 線回折ハンドブック, 理学 電機. $97(1999)$

6 ) 瀬戸雅宏，田中克，佐藤和人，山部昌：成形加工，14 (10)，671(2002)

7 ) 鈴木亨, 杉田寿夫, 瀬戸雅宏, 柿島浩徳, 田中宏明, 山部昌：成形加工，28(6)，239(2016) 